\title{
Writing Displacement
}




\section{Writing Displacement \\ Home and IDENTITy in Contemporary \\ Post-colonial English Fiction}

Akram Al Deek

palgrave
macmillan 


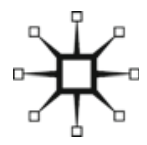

\section{WRITING DISPLACEMENT}

Copyright @ Akram Al Deek 2016

All rights reserved. No reproduction, copy or transmission of this publication may be made without written permission. No portion of this publication may be reproduced, copied or transmitted save with written permission. In accordance with the provisions of the Copyright, Designs and Patents Act 1988, or under the terms of any licence permitting limited copying issued by the Copyright Licensing Agency, Saffron House, 6-10 Kirby Street, London EC1N 8TS.

Any person who does any unauthorized act in relation to this publication may be liable to criminal prosecution and civil claims for damages.

First published 2016 by

PALGRAVE MACMILLAN

The author has asserted his right to be identified as the author of this work in accordance with the Copyright, Designs and Patents Act 1988.

Palgrave Macmillan in the UK is an imprint of Macmillan Publishers Limited, registered in England, company number 785998, of Houndmills, Basingstoke, Hampshire, RG21 6XS.

Palgrave Macmillan in the US is a division of Nature America, Inc., One New York Plaza, Suite 4500, New York, NY 10004-1562.

Palgrave Macmillan is the global academic imprint of the above companies and has companies and representatives throughout the world.

Hardback ISBN: 978-1-137-58091-7

E-PUB ISBN: 978-1-137-59249-1

E-PDF ISBN: 978-1-137-59248-4

DOI: $10.1057 / 9781137592484$

Distribution in the UK, Europe and the rest of the world is by Palgrave Macmillan ${ }^{\circledR}$, a division of Macmillan Publishers Limited, registered in England, company number 785998, of Houndmills, Basingstoke, Hampshire RG21 6XS.

Library of Congress Cataloging-in-Publication Data

Names: Al Deek, Akram, 1984-

Title: Writing displacement : home and identity in contemporary post-colonial English fiction / Akram Al Deek.

Description: New York: Palgrave Macmillan, 2016. | Includes bibliographical references and index.

Identifiers: LCCN 2015030570 | ISBN 9781137580917 (hardback) Subjects: LCSH: English fiction-20th century-History and criticism. | Identity (Psychology) in literature. | Displacement (Psychology) in literature. | Postcolonialism in literature. | Immigrants' writings, English-History and criticism. | Exiles' writings-History and criticism. | Collective memory in literature. | BISAC: LITERARY CRITICISM / Caribbean \& Latin American. | LITERARY CRITICISM / European / English, Irish, Scottish, Welsh. | LITERARY CRITICISM / Middle Eastern.

Classification: LCC PR888.13 A4 2016 | DDC 823/.91409353—dc23 LC record available at http://lccn.loc.gov/2015030570

A catalogue record for the book is available from the British Library. 
To my newly born nephew, in the hope this will speak to your generation. Welcome home, welcome to exile you little displacee! 


\section{CONTENTS}

Acknowledgments ix

Placing Displacement: An Introduction 1

$\begin{array}{lll}1 & \text { Writing Displacement } & 17\end{array}$

Section 1: Debunking the Nomadic Rhizome 17

Section 2: What Is Displacement? Answering by the Example of Nuzooh 23

Section 3: Nostalgia and Memory between Melancholy and Celebration 38

Section 4: Contrasting Palestinian Exilic Displacements and Jewish Diaspora 46

2 Displacing Cultural Identity $\quad \mathbf{5 7}$

Section 1: Cultural Identity between Ghettoization and
Displacements

Section 2: Racism and Immigration 67

3 The Windrush Generation: Remapping England and Its Literature $\quad 79$

4 Masala Fish: Cultural Synthesis and Literary $\begin{array}{ll}\text { Adventuring } & 117\end{array}$

Promoting Cultural Diversity/Multiculturalism Post-9/11: A Conclusion $\quad 165$

$\begin{array}{ll}\text { Notes } & 183\end{array}$

$\begin{array}{ll}\text { Bibliography } & 189\end{array}$

$\begin{array}{ll}\text { Index } & 197\end{array}$ 


\section{ACKNOWLEDGMENTS}

I thank the following, whose asset has been immense and whose contribution has been of great help in finishing this work:

My family for love and patience, friends and students for believing in me, and those who died for a home, for both their aspiration and inspiration.

This also goes to the resting soul of my uncle, may he rest in peace, who taught me how to ride a donkey, plant onions, and be careful in dealing with the colonizer; to the resting soul of my cat, whose purring kept me awake and sane during sleepless nights of research; to Al Jalil Football Club (Irbid Refugee Camp, Jordan) and Newcastle Panthers FC (Newcastle, UK) for reminding me what it means to be part of a group, to belong; to my father who taught me poetry, discipline, different types of figs, and punctuality; a German passport which allowed me crossing frontiers; to the resting soul of architect and friend Yousif Khatib, for sharing my daily existential madness and daydreaming; to the resting soul of photographer and friend Muhammad Al Zyoud, who taught me laughter during unbearable schooldays; my mother for teaching me pickling olives, the alphabets, ironing, and compassion.

I would also like to thank Dr Kathleen Kerr-Koch for her impetus, guidance, and thoughtfulness, for being an invigorating tutor and a caring friend; Dr Barry Lewis for several interesting conversations and channeling opinions; and Dr Geoffrey Nash for motivational support. I also thank the Culture and Regional Studies BEACON for its financial support and thriving academic enterprise, Dr Anastasia Valassopoulos, Dr Peter Dempsey, and Professor Peter Rushton for their instructive opinions, annotations, and criticism. Many thanks are also due to Professor Patrick Williams to have taken time despite and through illness to review my work; to my production editor, project manager, and editorial assistants and publisher at Palgrave Macmillan for their advice and cooperation. 